DOI 10.14746/ssp.2021.2.6

Ihor ISHCHENKO

Oles Honchar Dnipro National University

ORCID ID: 0000-0001-5799-7364

Olena BASHKEIEVA

Ukrainian State University of Chemical-Technology

ORCID ID: 0000-0001-7029-2465

\title{
Positioning and Rebranding as a State Security Tools in Global Space
}

\begin{abstract}
The purpose of this article is to explore positioning and rebranding as tools for state security in global space, using the methodology of constructivism in international relations. The author hypothesizes that positioning the country as safe will be attractive only if there is a unifying factor based on the principles of consocial democracy. To achieve this purpose, the authors used several scientific approaches and methods: constructivism as a scientific paradigm; dialectical method; content analysis, and comparison. The article covers the following issues: Positioning and rebranding in modern conditions; Level of branding effectiveness in Ukraine; National identity as the basis for rebranding and state security; Rebranding states in the face of new challenges and threats. The essence of the conclusions is as follows: States will choose a partner for economic cooperation under difficult conditions in terms of political risks, benefits, and costs. This trend is about renewed positioning and rebranding to facilitate decisions on cooperation. The effectiveness of the existing state brand depends not only on creating an attractive external picture of the country's positioning. Without a genuine alignment of the declared brand with the internal situation of the state, the political system as a whole, the congruent of the mental construct of the main political structures and the social environment, the brand will not be attractive to investors and the country will remain in an unstable environment.
\end{abstract}

Key words: positioning, rebranding, security, international relations, constructivism, identity, values, interests

\section{Introduction}

7 he modern world is facing new challenges, risks, and threats. They concern both individual states and their associations. Moreover, we have to state more and more often that along with the growing interde- 
pendence of states against the background of globalization, individual subjectivity is actualized, motivating, or stimulating to cooperation in various fields.

As international practice shows, even the most closed societies, such as North Korea, are looking for ways to expand their influence on the most economically developed countries, thereby attracting foreign capital necessary for developing their economies.

Synergetic explains such motives by the desire to increase the predictability and stability of economic development by increasing the entropy of investments and strengthening economic equilibrium within the state system.

In addition, international actors tend to use not stimulating (mainly hard power methods) but motivating methods of influencing partners, allies, and opponents (soft power, smart power). It is evident in the crisis conditions caused by the COVID-19 pandemic, environmental and climate change.

According to a recent speech by the US Secretary of State, Antony Blinken, America will no longer undertake "costly military interventions" or attempt to overthrow authoritarian regimes by force to advance democracy (Biden administration, 2021).

These methods have an undeniable advantage - they contribute to a more effective provision of state security and contain development potential. The positioning of the state in the international arena of interaction leads to certain types of its perception.

That is why the international level of interacting actors is filled with branding technologies. They aim to improve the perception of the state in the world, and the modern branding of states is periodically adjusted (rebranding).

We can note, and this is absolutely fair, that Ukraine looks like a clear outsider in this domestic and foreign policy component against the general background of post-Soviet countries. The evidence is the low level of direct foreign investment in our economy (Priami inozemni investytsii, 2021). It is worth analyzing the reasons for this negative position. The practice of communicating with residents of other countries shows that they have little or no idea about Ukraine. It can be seen even without additional research.

The other is obvious as well. It is important to analyze the condition of the domestic and foreign policy of the state because they affect the ability to implement positioning and rebranding in the interests of develop- 
ing the national economy and strengthening security not by force but by motivational methods. In other words, how not to position oneself as an ideal and attractive country, it is impossible to achieve the desired result if its created image is not filled with internal content, which is supported by the absolute number of individuals and groups. From this, it is possible to draw certain conclusions and make recommendations on what should be done to change the current trend for the better.

\section{Methodological grounds}

Analysis of modern research has shown that the concept of a state brand, characteristic of the 1990s, began to be actively applied to various territories: states, regions, cities, giving life to a whole direction - (place branding). The state brand concept was developed by many foreign experts: J. Hildreth (2010), S. Anholt (2006), W. Olins (2005), and others. Security branding was studied by Jon Coaffee, Peter van Ham (2008). Ukrainian researchers T. Nahorniak (2008), V. Myroshnychenko (2017), M. Tereshchuk (2015) also study the national branding of Ukraine. These scientific works do not focus on the transition of positioning to rebranding as a dynamic transition leading to a new perception of the country at the international level of interaction.

In addition, modern scholars do not actively use the possibilities of constructivism as a direction in the study of international relations. It can and should be used when discussing state security, its positioning, and rebranding. The article is based on the research of the classics of constructivism, such as A. Wendt (1995), N. Onuf (1989), and on the research of modern authors such as C. Ogden (2017), C. Braun (2020), S. Theys (2015), S. Romaniuk, F. Grice (2018), A. Rasheed (2020), and others.

The article also uses the features of the functioning of mental spaces by J. Fauconnier (1994) and The Strauss-Howe generational theory.

The purpose. Explore positioning and rebranding as instruments of state security in the global space, using the methodology of constructivism in international relations.

The authors' hypothesis is that positioning the country as safe will be effective only if there is a unifying factor based on the principles of consociational democracy.

To achieve this purpose, the authors used many scientific approaches and methods. Here are the main ones: 
- the research was carried out using constructivism as a scientific approach in the analysis of international interaction. This approach has helped to explore the specifics of identity, positioning, and dynamics, to assess the success of a state's domestic and foreign policies, to predict the behavior of states in the international arena and the patterns of rebranding;

- the dialectical method was used to demonstrate the rebranding of countries according with the rapid changes in international relations, the influence of economic, political, and other social factors. It is also focused on the probable future of relations between states in their reorientation from values to interests;

- there are methods of analysis and comparison to identify common trends toward modern rebranding and their features for each country, the reasons for the failed rebranding of Ukraine.

\section{Positioning and rebranding in modern conditions}

The nature of international life is largely determined by states' mutual beliefs and expectations about each other. Globalization has accelerated the processes of instability, greater attention to the identity in international relations, since identity allows to clearly define national and other international actors' interests, distinguish friends from enemies, allies of the enemies, thus setting the direction of development of international relations.

The world is changing rapidly, and with it is the understanding of social reality, which depends on the interpretation of conventional linguistic units; interests, values, identities, rules, and norms are the subject of transformation. Constructivism changes the paradigm of understanding the social construct, social norms, and rules, the identity of international actors as a process of formation in the course of symbolic and communicative interaction (Wendt, 1995). Our thoughts and actions build international relations. The distribution of material power, wealth, and geographic conditions can explain state behavior, ideas, identities, and norms. Reality is changeable; people create it themselves in their daily life (Onuf, 1989). These methodological principles of constructivism were used to study state security, its positioning, and the rebranding of states.

The image of a country influences its political and economic capabilities, international status, ability to influence other states and acts as one of 
domestic and foreign security policy resources. An effective image is an effective strategy for the development and strengthening of the country's competitiveness. Brand identity also matters, that is, a positive and recognizable identity of the state.

Interest in this topic is confirmed by the existence of whole research areas, such as public diplomacy, image-making diplomacy, nation branding, country branding, brand identity. We know that international journals have sprung up, such as Place Branding and Public Diplomacy, and many others researching this issue.

The positioning of the country is a recognizable image in the minds and hearts of people. France position itself as a country with a powerful gross domestic product (Mirovoy reyting, 2021), Japan is a high-tech brand (Sugaya, 2021), Switzerland is a "world safe" (Mazaraki, 2018, p. 11), Austria is a country of music, Denmark is a country of a "fairy tale" (Mazaraki, 2018, p. 11) and so on. What should be considered as the external structural foundation of the brand, and how is it created? Common branding tools are logos and slogans. Often spoken in commercials, "Malaysia is truly Asia" (Malaysia, 2021) or "Incredible India" (Tripti Ghosh Sharma, 2014) are remembered by millions of people around the world. Many countries have attractive logos, beautiful emblems with concise, catchy slogans such as "Australia Unlimited" (Olsen, 2010), "Amazing Thailand" (Amazing Thailand, 2021), "100\% Pure New Zealand" (Our Campaign, 2021), "Dynamic Korea" (Katherine In-Young Lee, 2015). It is common knowledge that the United States, a country of freedom, clearly knows its mission - to build democracy throughout the world and to give freedom to everyone. China has also decided on its "mission" - the construction of the "New Silk Road" and the spread of Eastern (Chinese) philosophy in business and politics (Navigating, 2020). South Korea (Dynamic Korea) - brings new technologies to everything. The country can sound differently and in a new way, for example - "Promised Land" (Israel). This name does not carry enough information to motivate tourists and other investors to come to Israel. The beginning of the 2000 s was marked by a new approach to the rebranding of this country. The slogan "Beautiful country and beautiful personality" changed the situation. Israel has become more popular for tourists (Herstein, 2013, p. 184). Such new forms of branding complement the official name favorably, and most importantly, they position the state on the world stage, give a short and clear answer to the question "What kind of country?" 
An unstable, changing world gives rise to the possibility of revaluation, a change in the perception of states in the range of enemy-rival-friend. Therefore, a key role in this process is changing states' positioning and branding. Recent years have shown how branding has changed in Estonia, Lithuania, Canada, Bhutan, and many others (Brending stran, 2018). In 2020, Lithuania created the Country image strategy for 2020-2030. And already selected position statement: Open for co-creation. One of the aims of this strategy is to create a country brand. The essence of new branding direction can be seen, for example, on postage stamps. The inscriptions on the stamps show the openness of the state, reveal the possibilities of peaceful cooperation with this country, the potential of green tourism, and more. It is a postage stamp in pastel mint colors. The font of the logo resembles living, growing tree branches, which emphasizes the natural aspect. Here are some of the inscriptions on these stamps: Lithuania. Real is beautiful. Explore culture. See nature. Stay active. Taste food. Meet people (Brending stran, 2018).

The rebranding of Canada uses the recognizable red lines of the Canadian flag as a frame for everything from icons to photographic images. The solution is simple, smart, and scalable, plus the most stamped stereotype - the maple leaf - is missing. Canada places these symbols on all material things associated with high quality and benefit for humans, thereby demonstrating to the whole world its image of a successful country, ready for cooperation, and this is true. There is only one principle here - new country symbols mean higher quality, which motivates cooperation.

Estonia is focusing on technological advances and innovative lifestyles in rebranding its country. Her new brand is broadcasting a new digital future. The old logo was accented with EST (the abbreviation of the country certified by ISO - International Organization for Standardization). The rebranding of e-Estonia focused on positive words starting with " $\mathrm{e}$ " in headlines and slogans " $\mathrm{e}$ " - Estonia, eco, efficiency, e-residence, e-society. It is also important that the symbolism of Estonia takes place in real life. Any subject would like to develop relations with such a progressive country (Brending stran, 2018).

Bhutan's rebranding focused on trade, crafts, organic farming, and clean energy. The yellow and red colors match the colors of the Bhutan flag and look good when paired with each other. Considering that good ecology means human health, this positioning will be successful (Theys, 2015). 
The rebranding of the Netherlands aims to renew the country's image. The government undertook a rebranding to eliminate the association with the Amsterdam red-light district and the reputation of a "paradise for drug addicts" associated with the more common name "Holland" in the world. In short, the rebranding of a country with a new name should be associated with safety for humans, which corresponds to the mental space of the country (Niderlandy, 2019).

One of the most successful examples of the country's rebranding is how Spain could completely rid itself of the negative image associated with the Franco dictatorship. As characterizing a prosperous, democratic state, Spain's modern, attractive image does not evoke any associations with the sinister Franco regime. Likewise, the image of modern Germany has nothing to do with the associations of fascism (Solomin, 2017).

The rebranding of the United States of America is manifested primarily in the change in slogans. If D. Trump in 2017 gave the word "Make America Great Again," "Let's return America to its former greatness," then Joe Biden used the slogans "Keep America Great" (2020), and subsequently - "Make America United Again" (2021) (Bayden zamenil izvestnyy slogan, 2020). As we can see, the President determined the direction of the rebranding of the United States to restore political stability to it, instill confidence in its allies that the country will continue to develop successfully.

The rebranding of China is due to the unstable global situation, the conditions of the pandemic. The goal is to convince other countries that China does not pose any threat to their interests. Xi Jinping's call at the World Economic Forum (2021) for mutual benefit, peaceful coexistence, "consultation and cooperation instead of conflict and confrontation" is a rebranding of the country's overall strategy and global image. China positions itself as a defender of the weak to preserve international laws and regulations, openness, unity, multilateralism instead of superiority (Oterbülbül, 2021).

Successful rebranding is a guarantee of state security. A frankly negative perception of the state affects the development of international relations, especially security. Modern political and economic conditions of interaction between states determine the dominant role of their image. If a state has an image of unprotected, with a high level of crime, the threat of a terrorist attack, or the risks of natural disasters, then it is doomed to problems of international cooperation (Fayzullayev, 2017). 


\section{Level of branding effectiveness in Ukraine}

T. Popova, Former Deputy Minister of Information Policy of Ukraine, an expert on strategic communications of the NGO "Information Security," assesses the image of Ukraine. According to T. Popova, the results of many studies have shown that until the end of 2013, Ukraine was perceived mainly as a young democracy in the transition period, a country of the Orange Revolution, famous athletes and beautiful women, certain high-tech sectors of the economy, as well as a non-influential, littleknown state, a center of political instability, corruption, and ineffective power and uncertainty of development, poor investment climate (Popova, 2018).

The events of 2018 showed a significant change in the perception of Ukraine abroad. A study supported by the British government summarized these perceptions of Ukraine by foreign citizens. The researchers found that the three most popular associations with Ukraine are "corruption", "revolution," and "war" (Sukhan, 2018). Undoubtedly, when they come to Ukraine, they see many positive and interesting things in our country, but the first impression is important. Otherwise, foreigners will not come to a country where it is dangerous to be. Thus, it is the rebranding that Ukraine needs to change its very negative perception. The rebranding should demonstrate to the whole world an open modern country - Ukraine, where all the most interesting is happening right now.

The positioning of a state in the world, including Ukraine, and its reputation in the eyes of the world community is a capital that allows it to promote its national interests in the international arena. The importance of forming a positive international image of Ukraine was emphasized in various regulatory documents. State programs for the formation of a positive international image of Ukraine have failed to improve the situation. They were planned for 2003-2006 and also until 2011. Specialists of that period focused Branding Ukraine on the dissemination of information about the traditional culture of Ukraine. Moreover, they ignored the development of modern culture and civil society. Also, the Ministry of Foreign Affairs of Ukraine made repeated attempts to use PR firms to improve the country's image abroad (Tereshchuk, 2015).

Ukraine's branding strategies of the past decade have changed several times. The concept "Ukraine. All about U" assumed the strategy "Ukraine - openness." A new logo and slogan of the country "Ukraine - moving in the fast lane" and slogans "High time to see Ukraine," "Ukraine Inspires" 
were developed. One of the information campaigns "Ukraine. Beautifully Yours" was intended to put an end to the idea of Ukraine as a great place for sex tourism and an exporting country for women.

The basis for positioning any country, especially rebranding, should be the desire for change, and the goal of rebranding should be specific changes. Mentioning the state's name (country brand) immediately evokes a chain of associations about this country, associated with its stability, security, hospitality, attractiveness for living and recreation, high quality of life. For example, Japan is a high-tech brand, France is a brand of high fashion and refined taste, Switzerland is the "world's safe," Austria is the country of music, etc. (Mazaraki, 2018, p. 11).

The International Tourism Exhibition (March 2018) ITB Berlin (Internationale Tourismus-Börse Berlin) showed the main trends and principles on which the brands are based. Thus, the stands of most countries were decorated in the same style. The slogans of many countries evoked memorable associations: "Amazing Thailand," "Costa Rica. My Choice. Naturally," "Wonderful Indonesia," "Israel. Land of Creation," "Palestine. The Holy Land" (ITB BERLIN, 2018). Ukraine was represented by the slogan: "Ukraine Open for U." The stand was decorated with inflatable dolphins, girls in police uniforms with a radiation sign were walking nearby. Are there any associations with safety and comfort? The mentioned symbols do not suggest security. The creation of the international image of the state is based on the generalizing imageidea of the country. Positioning and branding should form a congruent mental space in the external and internal environment of Ukraine. It will then be congruent when Ukraine is associated with a safe state, attractive for tourism and investment in the economy. Today we see the opposite trend. Capital investments in Ukraine decreased by $40 \%$ (Kapitalni investytsii, 2021).

\section{National identity as the basis for rebranding and state security}

Any, even the most beautiful, country brand will not withstand competition without a strong national identity. Values, norms common to all condition national branding. On the other hand, national security depends, among other things, on how correctly and successfully the value foundations of the state's brand policy are set in modern conditions. National branding can be seen as protection against the threat of destruction of the 
state's identity. The brand of the country is the image of the state that exists in the minds and hearts of the target audience. PR is a communication tool for an image, that is, a brand. Without an image, it gives a "Radio Effect," which is much noise, but no image.

In order to form a strategic goal, it is necessary to decide where the country wants and can move, how it sees itself in the future and whether this or that goal corresponds to its historical and cultural uniqueness, identity, and also whether the country has enough resources to achieve what it wants. Moreover, this task is relevant to everyone. Both government agencies and the general public, civil society, and the business community must work together to develop this strategic goal. Otherwise, the work on branding will not be effective.

"Security branding" is relevant to all countries today because of the COVID-19 pandemic. Changing the logic of branding affects the active promotion of state security. Key players in international politics, such as China, the US, and the strategic alliances of NATO, the EU use their brands of security, offer a sense of security.

The feelings of individuals and groups are largely constructed and amplified by the media. Fear and insecurity in the perception of another country create an image in mind: "friend - or rival - or enemy" rather in favor of the image of hostility. The media of Ukraine, as well as of any state, form a mental construct. In recent years, the Ukrainian media have used the terms "terrorists, separatists, militants, and war" very frequently, especially in the daily news. It causes a feeling of instability, a sense of fear, insecurity, and danger. It has a negative impact on the investment climate in the country (Kapitalni investytsii v Ukraini, 2021).

To alleviate the security problem, to prevent it from becoming a regional international problem entailing a brewing conflict, the source of the danger must be eliminated. In this regard, we note that the danger for Ukraine lies in the opposing values of the generations.

Four generations of Ukrainians, simultaneously living in the country, have largely different values, views on economic development, confessional orientations, and assessments of the past. There are also differences in identification along the north-west-east-south axis. These features must be taken into account in the rebranding of the country.

Today Ukraine is perceived as a country of corruption (Ukraine Corruption Index, 2021). Such perception forms fear, danger, rejection along the line of WE / THEY identification. When the country does not pose a threat in the eyes of others, it will strengthen the investment climate, 
strengthen the security of existence. To do this, it is necessary to remove the cause and resolve internal contradictions.

The authors agree with A. Leiphart's point of view on the necessary nature of democracy in multi-component societies, to which Ukraine belongs. In order to avoid conflicts of a destructive nature, such a democracy should be consociational (Lijphart, 1979, p. 500). The consociational strategy of conflict resolution is aimed not at superficial satisfaction of the interests of the opposing parties but at penetration into the sphere of values, the infringement of which, in fact, leads to a conflict. Such conflicts often arise in the conditions of compact residence of ethnic, religious, and other communities, whose interests are infringed upon at the level of central power structures. However, to implement a consociational strategy, one essential condition is that the electorate must trust political elites. In other words, representation of voters' interests at the elite level must be real and not imaginary. Therefore, political parties created on the initiative of the oligarchic elite, defending its interests, will by no means be able to resolve the situation. Unfortunately, in Ukraine, the top of the state bureaucracy creates both legal and illegal conditions for mafia channels of enrichment of industrial agrarian and financial oligarchies by mercilessly robbing the public majority, on the one hand, on the other, these oligarchies, in turn, "feed" the political leadership, state apparatus with shadow income.

We think that the first step toward the rebranding of Ukraine is creating a single, common, unifying identity based on consociational democracy. It is necessary to find a period of history that did not separate but was common and understandable to everyone. Alternatively, we need to find common symbols in different and contradictory histories, which would give positive belonging, identification of WE. Examples include the British monarchy, Kazakhstan, Ossetia, and other countries. It is the first step. Without an understanding of the common national idea, it is impossible.

The second step is to position the state and actualize its rebranding. To do this, it is necessary to remove fear in the country's perception by other subjects of international interaction. Move from the image of an enemy and rival to the image of a friend.

Dmytro Kuleba, Minister of Foreign Affairs of Ukraine, believes that Ukraine has not yet formed a unified global brand of the country, and there is no need to look for a national idea to form a brand of Ukraine (Kuleba, 2020). 
On August 24, 2020, Volodymyr Zelensky, President of Ukraine, launched a large-scale information campaign to relaunch the Ukraine NOW brand. He spoke about the new Ukrainian reality in a video message to the world community. The President said that Ukraine is no longer a country of poverty and corruption. Now Ukraine is a new technological center of the world, the granary of Europe with the most fertile lands, with huge tourism and investment potential. Ukraine is modern, young, peaceful, and hospitable, he said (Volodymyr Zelenskyi, 2020).

The facts say otherwise. According to the State Statistics Service, at the beginning of 2020, more than half of Ukrainians lived below the poverty line. Quarantine has only increased impoverishment, and by 2021 the number of poor people has increased (Intervyu, 2021). Ukraine's media gives a very unpeaceful picture every day in the news. Words are repeated many times in the news: war, terrorists, separatists, militants, and this causes a feeling of fear, danger.

Ukraine is one of the most corrupt countries in Europe. In 2018, Ukraine entered the top 30 most corrupt countries in the world with the corruption perception index of 32 points. In 2019 - 30 points, 2020 - 33 points (Ukraine Corruption Index, 2021). Ukraine's position in the international rankings and indices "measuring" the image, such as the index of underachieving countries, political risk index, human development index, press freedom index, the rule of law index, democracy index, global innovation index is not very high.

Such positioning of Ukraine by power institutions is not congruent with the mental structure of the social environment, which causes political instability and reduces the level of state security both within the country and at the international level. The mental space of a state as a dynamic unity of the mental constructs of political and economic entities determines the level of motivation to interact with other states. Mutually beneficial cooperation between the states based on mutual motivation is achieved by the congruent interference of their mental spaces. Such a situation is observed when the values associated with the assessment of the state experience, the ideas about the ideal political regime, the attitude toward the economic policy, and the prospects for states development and international cooperation between them have similar content (Ishchenko, Bashkeiva, Petrov, 2019, p. 10). Therefore, positioning the country without considering the main thing - common values - entails instability and harms the security of states in the international arena. 
Today, soft power and smart power strategies are recognized as the most effective way of positioning the state and promoting its interests (Nurnus, 2020). A nation's attractiveness and appeal are likely to still depend on its features and factual achievements, such as its level of development, international standing, credibility, quality of life, cultural output, and more. A nation should be aware of its potentially attractive features, some of which may be more useful and appreciated in certain contexts and not in others (Carminati, 2021). Strategy and diplomacy, along with political stability and competence, are essential factors for the existence of any state in a rapidly changing world.

In the twenty-first century, we are seeing increasing competition between countries. Coronavirus demonstrates that countries are ultimately self-interested and will cooperate with other countries based on utility and their ability to help them solve problems. A country's attractiveness to other countries will be based on shared interests, not shared values. In a world where competition rather than cooperation reigns, the practice of "soft power" will recede into the background, and "smart power" will increase.

It is noteworthy that it is during crises that people may want to change their perception of other countries. Thus, COVID-19 could mark China's transition from a global threat to a global leader. It is evidenced by China's success in eradicating poverty and announcing a free supply of Chinese vaccines to all countries in need (Xi declares, 2021). In a world of alliances and collaborative bargaining, values will play a diminished role. Saudi Arabia will care little about Israel's acceptance of LGBTS so long as Israel shares military technological innovations with alliance members. Kenya will care little about Germany's immigration policies so long as Germany holds sway over IMF loans in the Horn of Africa. Sweden will care little about Rwanda's constitutional reforms so long as Rwanda joins a trade alliance opposite an empowered China (Manor, Golan, 2020).

\section{Rebranding states in the face of new challenges and threats}

Thus, when rebranding countries, including Ukraine, a standardized, static image that fails to represent the new realities of the 21 st century should be abandoned. The main question each nation must answer is what solutions it can offer to other nations to help solve specific problems, pav- 
ing the way for strategic alliances. Norway can help the Baltic states with hydroelectronics. Israel can form its alliances in Africa by desalinating water. India can provide biopharmaceutical solutions to its neighbors (as it did during the COVID-19 outbreak). As the world changes, the nature of power changes with it. The time has come to abandon the concept of hard power and move to soft power and smart power.

Country branding is the formation and promotion of its unique, attractive, and recognizable image, which is perceived both within the country by the entire population and the international community. The positioning of each country today is closely related to the answer to the question: What can you do for me? How can I help you solve specific problems? The importance of strategic assessments being conditioned by mutual expectations is increasing today. It means that mental images of countries as instruments of contemporary international security policy are becoming increasingly important. The country's rebranding should be based on the idea of an active subject that creates new knowledge, images, and mutual perceptions, changing the world and making existence safe.

\section{Conclusions}

The study makes it possible to draw several conclusions. Rapid changes in the world and crisis conditions are forcing states to reassess the strategy of interaction in the international arena. Ideological factors motivating cooperation based on the congruence of political systems are beginning to fall out of favor.

Modern states will choose a partner for economic cooperation in the difficult conditions of the pandemic and the economic crisis caused by it. First of all, states assess it in terms of political risks, benefits, and costs. This trend is updating positioning and rebranding to simplify decisionmaking for cooperation. In turn, the desire to take an advantageous place in the international system of interaction, which allows attracting foreign direct investment, has led to a high-quality and dynamic renewal of states' brands. Such actions occur in many countries. However, the effectiveness of a state's current brand does not simply depend on creating an attractive external picture of a country's positioning. Without the true conformity of the declared brand to the internal situation in the state, the political system as a whole, the congruence of the mental construct to the basic political 
structures and the social environment, the brand will not be attractive to investors and the country will continue to be in conditions of instability.

\section{Bibliography}

Amazing Thailand (2021), “TAT”, https://amazingthailand.com.au, 15.05.2021.

Anholt S. (2006), Brand New Justice: The Upside of Global Branding, Butterworth Heinemann, Oxford.

Biden administration establishes China competition as key strategic focus (2021), "TheStraites Times", 03.03.2021, https://www.straitstimes.com/world/united-states/us-secretary-of-state-antony-blinken-calls-china-biggest-test-vowsus-strength, 14.03.2021.

Bayden zamenil izvestnyy slogan Trampa [Biden replaces Trump's famous slogan] (2020), “Tengrinews", 09.11.2020, https://tengrinews.kz/life/amerikanskayagazeta-ozvuchila-novuyu-prichinu-razvoda-billa-437439/, 23.05.2021.

Braun C. (2020), The Virtue of Being Small: An Analysis of Luxembourg's Defence Strategy, "E-International Relations", 20.03.2020, https://www.e-ir. info/2020/03/20/the-virtue-of-being-small-an-analysis-of-luxembourgs-defence-strategy/, 14.03.2021.

Brending stran [Country branding] (2018), "Dreambrand.studio", 28.07.2018, https:// medium.com/@DREAMBRAND/\%D0\%B1\%D1\%80\%D0\%B5\%D0\%BD\%D0\%B4\%D0\%B8\%D0\%BD\%D0\%B3-\%D1\%81\%D1\%82\%D1\%80\%D 0\%B0\%D0\%BD-a6cc337af057, 14.03.2021.

Carminati D. (2021), Contextualizing Soft Power's Analysis: The Value of Attractive National Features, "E-International Relations", 08.02.2021, https://www.eir.info/2021/02/08/contextualizing-soft-powers-analysis-the-value-of-attractive-national-features/, 15.03.2021.

Coaffee J., van Ham P. (2008), 'Security branding': The role of security in marketing the city, region or state, "Place Branding and Public Diplomacy", vol. 4, pp. 191-195.

Fayzullayev A. (2017), Strana kak brend, "Gazeta.UZ", 19.04.2017, https://www. gazeta.uz/ru/2017/04/19/country-branding/, 15.05.2021.

Fauconnier G. (1994), Mental spaces: Aspects of meaning construction in natural language, Cambridge University Press, Cambridge.

Herstein R., Berger R. (2013), A country as a brand: Israel's evolving branding strategy, "Journal of Brand Strategy", vol. 2, no. 2, pp. 179-190.

Hildreth J. (2010), Place Branding: a View at Arm's Length, "Place Branding and Public Diplomacy", no. 6, pp. 27-35.

Intervyu s demografom. (2021), "Liha.Biznes", 26.01.2021, https://biz.liga.net/ pervye-litsa/all/interview/akademik-ella-libanova-karantin-i-distantsionnoeobuchenie-usilivayut-neravenstvo, 15.03.2021. 
Ishchenko I., Bashkeiva O., Petrov P. (2019), Empirical model of mental space congruence as a tool for international relations analysis and changes, "Economic Annals-XXI", vol. 176, Issue 3-4, pp. 1-13, doi: https://doi.org/10.21003/ ea.V176-01, 15.03.2021.

ITB BERLIN 2018 (2018), "Berlin Visual”, 12.03.2018, https://berlin-visual.com/ ITB-Berlin-2018--Ukrainskiy-natsionalnyi-stend, 23.05.2021.

Kapitalni investytsii v Ukraini vpaly na 40\% [Capital investments in Ukraine decreased by 40\%] (2021), "Ekonomichna Pravda", 25.02.2021, https://www. epravda.com.ua/news/2021/02/25/671385/, 23.05.2021.

Katherine In-Young Lee (2015), Dynamic Korea: Amplifying Sonic Registers in a Nation Branding Campaign, "The Journal of Korean Studies", vol. 20, no. 1, pp. 113-147, https:/www.jstor.org/stable/43919310?seq=1, 15.05.2021.

Kuleba D. (2020), "Ne treba shukaty natsionalnu ideiu”. Kuleba pro te, chomu Ukraina dosi bez brendu [No need to look for a national idea. Kuleba about why Ukraine is still without a brand], “Ліга.Life", 25.11.2020, https://life. liga.net/poyasnennya/news/ne-nado-iskat-natsionalnuyu-ideyu-kuleba-otom-pochemu-ukraina-do-sih-por-bez-brenda, 15.03.2021.

Lijphart A. (1979), Consociation and Federation: Conceptual and Empirical Links, "Canadian Journal of Political Science", vol. 12, no. 3 (Sep. 1979), pp. 499515, http://fbemoodle.emu.edu.tr/pluginfile.php/44346/mod_resource/content/1/Lijphard\%201979.pdf.

Malaysia is truly Asia (2021), "Malaysia. Travel", 15.05.2021, https://www.tourism. gov.my/campaigns/view/malaysia-truly-asia.

Manor I., Golan G. (2020), The Irrelevance of Soft Power, "E-International Relations", 19.10.2020, https:/www.e-ir.info/2020/10/19/the-irrelevance-of-softpower/, 15.03.2021.

Mazaraki A., Melnychenko S., Melnyk T., Tkachenko T., Hladkyi A., Bai S., Piatnytska G., Avdan O., Hryhorenko O., Dupliak T., Zabaldina J., Kandahura K., Lukashova L., Prysiazhnyuk A., Varibrusova A. (2018), National Brand of Ukraine: Monograph, eds. A. Mazaraki, Tallinn.

Mirovoy reyting stran po VVP v 2019 godu: Statistika [World Ranking of Countries by GDP in 2019: Statistics] (2021), "Knoema", 14.05.2021, https://knoema. ru/nwnfkne/мировой-рейтинг-стран-по-ввп-в-2019-году-статистика, 23.05.2021.

Myroshnychenko V. (2017), Nashe zavdannia zrobyty tak, shchob sumnykh istorii ne bulo [Our task is to make sure that there are no sad stories], "Liha interniv", 19.04.2017, http:/www.interns.org.ua/uk/content/nashe-zavdannya-zrobyty-tak-shchob-sumnyh-istoriy-ne-bulo-vasyl-miroshnychenko-pro-imidzh, 14.03.2021.

Nahorniak T. L. (2008), Kraina yak brend. Natsionalnyi brend "Ukraina" [Country as a brand. National brand "Ukraine"], "Stratehichni priorytety", no. 4(9), pp. $220-228$. 
Navigating the New Silk Road (2020), “WPP”, 10.11.2020, https://www.wpp.com/ wpp-iq/atticus-awards/atticus-journal-v25/navigating-the-new-silk-road, 23.05.2021.

Niderlandy, a ne Hollandiia: kraina rozpochynaie hlobalnyi rebrendynh [The Netherlands, not the Holland: the country is begining on a global rebranding] (2019), "Yevropeiska Pravda", 04.10.2019, https://www.eurointegration.com. ua/news/2019/10/4/7101561/, 15.05.2021.

Nurnus M. (2020), Soft Power: Can Less be More?, "E-International Relations", 15.04.2020, https://www.e-ir.info/2020/04/15/soft-power-can-less-be-more/, 23.05.2021.

Ogden C. (2017), Perception and Evolution in the Making of China and India as Great Powers, "E-International Relations", 25.05.2017, https://www.e-ir. info/2017/05/25/perception-and-evolution-in-the-making-of-china-and-india-as-great-powers/, 14.03.2021.

Olins W. (2005), Branding the Nation - the Historical Context, "Journal of Brand Management", vol. 9, pp. 241-248.

Olsen D. (2010), 'Australia Unlimited'sells Brand Australia to the world, "DYNAMIC BUSINESS", 17.05.2010, https://dynamicbusiness.com.au/topics/smallbusiness-resources/growth-import-export/australia-unlimited-brand-1527. html, 15.05.2010.

Onuf N. (1989), World of Our Making: Rules and Rule in Social Theory and International Relations, University of South Carolina Press, Columbia.

Oterbülbül S. (2021), Rebranding China's Global Role: Xi Jinping at the World Economic Forum, "E-International Relations", 20.02.2021, https://www.e-ir. info/2021/02/20/rebranding-chinas-global-role-xi-jinping-at-the-world-economic-forum/, 15.03.2021.

Our Campaign 100\% Pure New Zealand (2021), "The site of the company", 15.05.2021, https://traveltrade.newzealand.com/en/working-with-us/100pure-new-zealand/, 15.05.2021.

Popova T. (2018), Nash imidzh. Kak Ukrainu vosprinimayut v mire [Our image. How Ukraine is perceived in the world], "NV", 21.03.2018, https://nv.ua/opinion/ nash-imidzh-kak-ukrainu-vosprinimajut-v-mire-2459084.html, 15.03.2021.

Priami inozemni investytsii (PII) v Ukrainu [Direct foreign investments in Ukraine] (2021), "Minfin", 15.04.2021, https://index.minfin.com.ua/ua/economy/fdi/, 24.05.2021.

Rasheed A. (2020), Climate Ideas as Drivers of Pacific Islands' Regional Politics and Cooperation, "E-International Relations", 15.01.2020, https://www.e-ir. info/2020/01/15/climate-ideas-as-drivers-of-pacific-islands-regional-politicsand-cooperation/, 14.03.2021.

Romaniuk S., Grice F. (2018), Norm Evolution Theory and World Politics, "E-International Relations", 15.11.2018, https:/www.e-ir.info/2018/11/15/normevolution-theory-and-world-politics/, 14.03.2021. 
Solomin E. (2017), Strana kak brend [Country as a brand], "Livejournal”, 28.04.2017, https://evgenysolomin.livejournal.com/619884.html, 15.05.2021.

Sugaya N. (2021), Top 10 Japanese Tech Companies in 2021, "Freshtrax", 23.04.2021, https://blog.btrax.com/top-10-japanese-tech-companies/, 23.05.2021.

Sukhan R. (2018), Novyy brend Ukrainy: "eto ne dlya ukraintsev" [New brand of Ukraine: "this is not for Ukrainians"], "BBC NEWS. Ukraine", 11.05.2018, https://www.bbc.com/ukrainian/news-russian-44079893, 15.05.2021.

Tereshchuk M. Y. (2015), Brendingovyye tekhnologii vo vneshney politike Ukrainy: normativnyye $i$ organizatsionnyye aspekty [Branding Technologies in Ukraine's Foreign Policy: Regulatory and Organizational Aspects], "Studia Humanitatis", no. 3, http://st-hum.ru/content/tereshchuk-mi-brendingovyetehnologii-vo-vneshney-politike-ukrainy-normativnye-i, 14.03.2021.

Theys S. (2015), Bhutan's International Presence and the 2018 World Cup Qualifiers, "E-International Relations", 30.03.2015, https://www.e-ir. info/2015/03/30/bhutans-international-presence-and-the-2018-world-cupqualifiers/, 14.03.2021.

Tripti Ghosh Sharma (2014), Incredible India: Evolution of Brand India, "Harvard Business Review", 30.07.2014, https://store.hbr.org/product/incredible-indiaevolution-of-brand-india/W14314, 15.05.2021.

Ukraine Corruption Index (2021), "Trading Economics", 15.03.2021, https://tradingeconomics.com/ukraine/corruption-index, 15.03.2021.

Volodymyr Zelenskyi perezapuskaie brend Ukrainy Ukraine NOW (2020), "Embassy of Ukraine to the Holy See", 24.08.2020, https://vatican.mfa.gov.ua/news/ volodimir-zelenskij-perezapuskaye-brend-ukrayini-ukraine-now, 15.03.2021.

Wendt A. (1995), Constructing International Politics, "International Security", vol. 20, no. 1, pp. 71-81, https://www.jstor.org/stable/2539217?seq=1, 14.03.2021.

$X i$ declares "complete victory" in eradicating absolute poverty in China (2021), "XINHUANET", 15.03.2021, http://www.xinhuanet.com/english/202102/25/c_139765861.htm, 15.03.2021.

\section{Pozycjonowanie i rebranding jako narzędzia bezpieczeństwa państwa w przestrzeni globalnej}

\section{Streszczenie}

Celem artykułu jest zbadanie pozycjonowania i rebrandingu jako narzędzi zapewniających bezpieczeństwo państwa w przestrzeni globalnej przy użyciu konstruktywizmu w stosunkach międzynarodowych. Hipoteza zakłada, że pozycjonowanie kraju jako bezpiecznego byłoby atrakcyjne tylko wtedy, gdy istnieć będzie czynnik jednoczący oparty na zasadach demokracji konsocjonalnej. Aby sprostać temu założeniu, autorzy zastosowali szereg perspektyw i metod naukowych: konstruktywizm jako paradygmat naukowy; metodę dialektyczną; metody analizy treści i porównawczą. 
W artykule omówiono następujące kwestie: pozycjonowanie i rebranding w nowoczesnych warunkach; poziom skuteczności brandingu na Ukrainie; tożsamość narodowa jako podstawa rebrandingu i bezpieczeństwa państwa; rebranding państw w obliczu nowych wyzwań i zagrożeń. Wnioski są następujące: państwa wybierają partnera do współpracy gospodarczej w trudnych warunkach, szacując ryzyko polityczne, korzyści i koszty. Trend ten polega na aktualizacji pozycjonowania i rebrandingu w celu ułatwienia podejmowania decyzji o współpracy. Skuteczność istniejącego brandu państwowego zależy nie tylko od stworzenia atrakcyjnego zewnętrznego pozycjonowania kraju. Bez prawdziwego dostosowania deklarowanego brandu do faktycznego statusu państwa, jego systemu politycznego jako całości, a także głównych struktur politycznych i środowiska społecznego, brand nie będzie atrakcyjny dla inwestorów, a państwo pozostanie w niestabilnym środowisku.

Słowa kluczowe: pozycjonowanie, rebranding, bezpieczeństwo, stosunki międzynarodowe, konstruktywizm, tożsamość, wartości, interesy 
